\title{
Al-Karnak by Najib Mahfudz: Anatomy of Sovereignty, Inequalities, and Dilemmas of Humanity
}

\author{
M. Hafidzulloh S.M ${ }^{1}$, Aprinus Salam²,* \\ ${ }^{I}$ Magister Ilmu Sastra Fakultas Ilmu Budaya Universitas Gadjah Mada, Indonesia \\ ${ }^{2}$ Magister Ilmu Sastra Fakultas Ilmu Budaya Universitas Gadjah Mada, Indonesia \\ *Corresponding author. Email: aprinus@ugm.ac.id
}

\begin{abstract}
Humanity has been the main topic in some of Najib Mahfudz's works. However, Najib Mahfudz's works, which make narratives about humanity, are motivated by an overview to describe social inequality. Thus, this research assumes that the humanitarian issues have been the main discussion in several of Najib Mahfudz's works. In alKarnak, both social inequality and humanity are two issues highlighted sharply. The narration presented by Najib intersects with citizens who are in post-war crisis conditions, of course, the sovereignty becomes a power to get formal legality. Therefore, this paper discusses anatomy sovereignty, biopolitical life, and humanitarian dilemmas from Giorgio Agamben's perspective. The data research is textual data from the novel al-Karnak. This study found that the gap was created by cultural and structural domination. In addition, the biopolitical life directs citizens under the biopolitical living system by referring to and affirming the existence of sovereignty.
\end{abstract}

Keywords: Sovereign Power, Biopolitics, Agamben, Al-Karnak.

\section{INTRODUCTION}

Some of Najib Mahfudz's works incline to describe the social reality of the Egyptians. Particularly after the government coup, which was marked by the end of absolute monarchy. The coup resulted in King Farouk, who was then the legitimate chief of the Egyptian government, being forced to resign from the number one position in Egypt. The long series of events and political turmoil in Egypt that occurred in 1952, is the main factor in the transformation of Najib Mahfudz's works from the surrealist to the realist genre. This pattern is presented by Najib in the form of a picturization of the middle class, lower class, and several immigrant groups in the city of Cairo who lack attention in terms of social welfare [1][2].

In addition, the contribution and existence of Najib Mahfudz's work in Arabic literature are very much taken into account. This reason is emphasized because, in 1988, Najib won the Nobel Prize in Arabic literature with his famous work [3]. There are three works, namely Bain al-Qasrain (1956), Qasr al-Shauq (1957), and al-Sukkariyah (1957) which made Arabic prose recognized by the world community [4][5].

As one of the leading writers in Egypt, almost all of Najib Mahfudz's works intersect with the social and political conditions that are entwined in it [6]. These various social moments and events become the foundation for building narrative stories in some of his works. Taking ideas to see social reality, especially those from the working class or below, is the main locus that is studied very sharply [7].

In addition, there are several factors apart from the economic viewpoint, the defeat of Egypt's war against Israel in 1967 was a moment in which all Egyptians were in deep sorrow. The most prominent impact of this defeat is the formation of identity-based frictions. From all these frictions, they are transformed into the realm of the meaning of nationalism. Thus, the meaning of nationalism is no longer a basic benchmark in creating a high sense of patriotism towards the state, but rather towards a meaning consisting of several understandings. Therefore, this understanding of nationalism becomes a discursive arena with several 
discourses on how and what attitudes are displayed or become dominant in its structure [8].

The interesting point in al-Karnak's novel relates to the author's narrative strategy which presents more than the factors of the defeat of Egypt's war against Israel. More than that, the author intends to make this novel a manifestation of historical documents that are actualized in literary works [9]. Therefore, what is conveyed by the author of a literary work will be closer to the social and human elements.

The formulation of the main problem to examine Najib Mahfudz's al-Karnak relates to seeing how a sovereign crisis is presented when the country experiences an emergency due to war. Hence, it is noticed that the citizens of the country started the conflict with each other thus creating an impact on the internal turmoil of civilians. In the context of the suspension of state sovereignty, there are two main aspects to see how the logic of the suspension of sovereignty is addressed in the name of the integrity of the state. Both sides of the suspension are positive and negative. How the impact and what effects it had after the war became a common thread in taking the main research problem.

Based on the above formulation, the main objective of this research is to discover more about how the suspension of sovereignty is constructed and its working logic is carried out to maintain the stability and constellation of the state. In addition, to explain how this goal is, in this case, the researcher examines several previous studies, both the similarities of the material and formal objects used in the study.

Al-Karnak is the name of a cafe located on the alMahdi street on the outskirts of Cairo. In this cafe space, there are characteristics of a heterotopia space that play a role in creating several variations of space, because basically, the characteristics of this heterotopia space are the articulation of the forms of dystopia and utopia [10]. In addition to the spatial characteristics, in the narrative structure of al-Karnak, there is also an author's world view that leads to the view of democratic socialism [11].

The narrative and storytelling techniques in alKarnak's novel mostly use the first-person pronoun "I" throughout the story. This technique indicates that the pronoun is in direct contact with the author [12]. Meanwhile, in another case, the structure of al-Karnak contains a plot, time-place setting, and style of language in a typical Arabic literary perspective using the landscape of balaghah science [13].

Based on the formulation and objectives of the research, in the context of this research, the sociology of literature from the perspective of Giorgio Agamben is used to examine the object. The existence of literary works is a form of Agamben's main investigation regarding sovereign power as a space in which the law acts as a fundamental weapon in citizens reduced due to various demands. Departing from the thoughts of Walter Benjamin in his notes entitled Critique of Violence [14] in detail explains how the legal conception when they encountered the complicated problems of citizens. Benjamin captures that the law acts when the state is on track to maintain stability between the government and citizens [15]. However, there are conditions when the state is faced with internal instability that requires it to act more accommodatively.

The presence of political life for citizens is conceptualized as a pathway to achieve a sovereign state. The mechanism used in the process of internalizing citizens in political calculations is by establishing several practices and the fusion of government discourse in every citizen. On this basis, the state has the right to regulate, control, and at the same time make citizens involved in the political process. Agamben sees this symptom appearing especially in countries that implement democracy in the contemporary era because they often ignore the main foundations of citizen law [16]. Finally, sovereign power works based on its capacity as violent behavior [17], as well as eliminating the limitations of citizens' lives who struggle with the practice of despotic power [18].

The common ground that can be inferred from the concept, as well as the theoretical spirit expressed by Agamben, is to see the basic form of the citizen. The anatomy of the citizen is radically explained by Agamben to reveal various instruments of state constitutional authority represented by the constitutional-executing power in handling and configuring sovereign power. As could be seen in the novel Al-Karnak which tries to narrate authoritative forms of government towards citizens. The beginning of the story starts with the journey of the narrator who wants to repair a watch on a street which then finds the Karnak cafe. It is from this cafe that the discussion about the political attribution of citizens begins.

\section{RESEARCH METHOD}

This research is categorized as qualitative research by describing the research data descriptively. It is said so because the data in literary research are in the form of words, sentences, and paragraphs contained in the object of research. There are two research objects, the first is the formal object, and the second is the material object. Formal objects are aspects or elements that will 
be discussed in research or related to certain points of view in studying literature [19]. While the material object is the existence of the literary work itself in the form of the novel al-Karnak by Najib Mahfudz. Textual data from material objects are used as the main data source and some other literature that correlates with the research subject is used as a data source for the second study.

\section{DISCUSSION}

\subsection{Rationalization of Power-Sovereign Authority}

The modern democratic paradigm that upholds the construction of humanism in the contemporary era is faced with complicated problems caused by the dynamics of citizens internally. Rationalization in the form of legal formal included in the principle of the state constitution is authorized to legitimize power. The highest authority of sovereign power has absolutism that can provide legitimacy for the consumption of public discourse. This legality triggers the emergence of the paradigm or logic of the government system that has been agreed upon and becomes a common will. In this process, the authority of power was born by turning citizens into bio-political figures.

Muslims as the majority religion adopted by the Arabs after the defeat of the war considered the idea of Arab nationalism to be unsuccessful in answering the problems of Muslims. They refused and at the same time gave the option of forming an Islamic state by exclaiming loudly to the government. However, the government at that time refused and was repressive towards these voices.

"There came a day when I arrived at the café only to nd all the chairs normally occupied by the young people empty. The entire place looked very odd, and a heavy silence hung over everything." (Mahfudz, 2008: 16).

The cafe looks quiet by leaving empty chairs no one occupies. This situation is unlike the previous days where this cafe is always crowded with visitors who want to relax while enjoying some dishes from this cafe. The young people who usually come to the cafe to discuss social conditions have stopped without any concrete reason. The absence of the young people in the cafe raises many questions about their whereabouts. The café that used to look crowded now looks deserted without the presence of the youths

There is a dominant tendency related to the disappearance of the youths because they all leave big questions and are difficult to find solutions to. Because of that, this incident became an irony for the other visitors since they wondered about the main reason why the youths disappeared without anyone knowing. This incident inevitably creates a sad feeling for all relatives who know them closely.

The government's failure to balance political stability and constellation at that time gave rise to a social crisis. When the crisis occurs over a long period, it will awaken many people's awareness. At the same time, this is the momentum when the discourse of normalizing the emergency is widely circulated in the community. Normalization is used to form submissive citizens - submissive in terms of citizenship politics. This action was taken when the state needed structures and opportunities for citizen mobilization to sustain its sovereignty despite repeated arrests. Therefore, the act of arrest and exile can become the legality of political reasoning with the reference that these actions seek to accommodate the state life.

"And then, right in the middle of spring, they all vanished for a third time. On this occasion no questions were asked, and there were no violent reactions either. We just stared at each other, shook our heads, and said something or other that made no sense." (Mahfudz, 2008: 30).

For the umpteenth time, the young people were gone with no reason. By building assumptions to guarantee state sovereignty, interrogation and exploitation of citizens are used to limit and shackle citizens from the panoptic of sovereign power. This repeated incident made the other visitors no longer felt as lost as the first time. This is because the presence and absence of these youths is a familiar occurrence for them. For this reason, the only reaction that can be expressed is to surrender and wait for their return to tell what happened when he was under arrest.

During this incident, when mass arrests became paradoxical, other cafe patrons did their best to protect themselves from the intervention that was raging, both culturally and ideologically. To maintain this, they straightforwardly voiced the main conception that emerged when the revolution was achieved by all civilians. Defining the future of the nation continuously invites a long debate, moreover, it triggers an ideological-based contestation by offering an ideal form of government.

The disappointment that was engulfing the cafe's visitors explained how the chaos that had been going on for a long period happened. This condition caused feelings of disappointment for cafe visitors who were not involved in the arrest. However, they are still looking for information on the chronology of the arrests involving their close friends. When the discussion about the reasons did not yield satisfactory results, they all hoped positively for a brighter future. 
"In the days and years that followed I kept close track of this tendency, until its basic tenets and variegated manifestations were clearly visible. The June War of 1967 was a defeat for one Arab nation, but also a victory for other Arabs" (Mahfudz, 2008: 32).

While remembering some previous events, they attempted to reflect on the forward navigation of the Egyptians. The events of the June 1967 war brought them to the brink of a slump and a democratic emergency. However, the defeat was not accompanied by the existence of other Arab countries that did not feel the defeat. It is clear from this that it can be seen how the defeat was felt by the Egyptians, followed by several other Arab countries. This defeat is seen as a concrete manifestation rather than a simulation of how the constellation was going on at that time. Although this looks pessimistic, the act of suspending oneself is the best way to avoid the practice of legalizing despotism from sovereign power.

Self-restraint not to be in the sense of acting to keep themselves from the continuity of mass arrests. Not to mean that they are in a position to refrain from becoming a part of the political prisoner. Because to remain consistent and maintain their identity in the public sphere will undoubtedly bring disaster due to the activities of the polymatization of sovereign power. In the end, the sovereign power has the right to determine whether to take the law and suspend the law [20].

The concept of solidarity that comes from cafe visitors in seeing the social reality when the arrests occur and the future can be described to determine progressive steps. It means that the particularity between the common will between the state and citizens is still a long debate. For that reason, this desire will continue to be shackled by partiality which leads to provocations from both the community and government levels.

\subsection{Exceptions vis-à-vis the Legality of Violence}

Various possibilities and claims from the implementation of democracy will bring huge changes to the progress of a nation. This reason is indeed the basic assumption in a democracy. However, as stated by Agamben, in the implementation of the democratic system there are irregularities in respect to the constitution and institutionalization of the state in terms of social order. This means that there is still a lot of work that has not been completed in detail concerning the conception and arrangement of citizens. It is for this reason that triggers horizontal and vertical friction in the construction of state life. Therefore, it is common to find spaces created by sovereign powers to blur the boundaries between humans and their animal forms-concentration camps.

A sharp critique of concentration camps is assumed to be a space that is an integral part of sovereign power [21]. This space is a place to carry out several dehumanizing practices against the residents in it. This is where Agamben rejects the concept because it is considered far from the definition of humanization echoed by democratic countries [22].

Starting from the explanation above, in regards to the narrative of sovereignty carried out by the government against several figures, among others, Ismail and Zainab became people whose norms were reduced as entities of citizens. This was due to the strong influence of the heating up of the political constellation at that time. In the end, the two of them only acted to surrender themselves who voluntarily allowed himself to be tortured in a prison cell.
"One day I was summoned to Khalid Safwan's oce while Isma'il was being interrogated. When I saw how humiliated and hopeless he looked, tears welled up in my eyes. From the very bottom of my heart I poured curses on the world. But I was only there long enough for him to hear the threat of my being tortured. I was taken back to my lthy cell where I cried for a long time. Day after day the torture continued" (Mahfudz, 2008: 63-64).

When Zainab was arrested and put in prison for interrogation, it was related to the suspicions that had required Khalid to find the answer directly. With inhumane treatment described from the quote above, it can be seen how Zainab's first response was when she met her best friend Ismail when being interrogated. From that incident, Zainab felt anxious and afraid if a similar measure could be imposed on her. In the end, she could only express her feelings of disappointment from within to reject everything that happened at that time.

Regarding the consistency of the state in ensuring the stability of sovereignty, it is often synonymous with coercive action against citizens who have different views. Zainab's outburst of anger that can only be expressed in her heart emphasizes that she strongly rejects this action. However, this is also related to his existence which does not have broad accessibility. Therefore she only responded in silence. Likewise with Zainab's presence when Ismail received harsh treatment from the apparatus when asking several questions as well as stripping himself of the singularity aspect as a citizen. 
Their existence in prison is a representation of the paradigm of sovereign power which justifies any means in the name of state stability. Both Zainab and Ismail, who are in prison cells, are vulnerable subjects to violence. The violence is not in the sense of violating the human rights of both of them, but the legality of the violence has been established in a separate entity so that its legitimacy cannot be terminated. Subjectivation of citizens becomes a natural measure because it is in the context of state stability.

The procedures and/or logic of exception are used by the power to legitimize its authority as well as to reproduce the authenticity of sovereignty. This condition triggers feelings of immeasurable anxiety for some of the youths who experienced it in the quote below:

"The only people left now are those old men who have all completely forgotten about the other customers in prison; there they are, pretending to ignore the terror and politics by burying themselves in their own private worries. For them the only job left, it would seem, is sitting around and waiting for their nal hour to come. Now they rue the passing of the good old days. Their only secret purpose in exchanging weird prescriptions is to postpone their appointment with death." (Mahfudz, 2008: 26)

A picture of the situation that occurs when all of them have given themselves up and leave no room to be able to preserve the desire for a better life. The waves of commotion that come and go are responded to by surrendering life and burying deep hopes of becoming an attribute-free human. However, what happened was contrary to that expectation, they were all plunged into a puddle of doom by simply discussing whether all of them would die from the same mistake. Therefore, the issue of human freedom as an individual is only a pseudo-structure with a high imagination of liberation in the structure of modern democracy.

This situation brings an understanding related to the form of submission to state sovereignty not only in an administrative context but also involves a combination of managerial bodies that are subject to it. Thus, the mainline that distinguishes between freedom and abandonment becomes blurred and even becomes a solid building of legitimacy. It is true when the sacredness of the body becomes a topic in the production of the meaning of equality from the perspective of basic human rights. Mechanisms to shape and define society on a national scale, especially when there are external and/or internal pressures that seek to undermine sovereign power. For this reason, sovereignty can present a culture of state life that is adapted to the metanarrative of sovereign power.

"It was nighttime," he said. "I was asleep on a bench in the yard. In spring and fall I always do that so as to leave the single room for my father. I was sound asleep. Gradually I became aware of daylight impinging on my sleep like a dream. Someone was shaking me roughly. I woke up, opened my eyes, but found myself blinded by a powerful light shining right into my eyes" (Mahfudz, 2008: 42).

The setting of the place and time of the quote above illustrates Ismail's concern. That feeling keeps haunting him when it is time to rest, thereby what he feels is no longer a human being who can feel freedom in the true sense, he is always monitored by security forces, and becomes an object of discipline. By being forced to follow the police for interrogation regarding the news circulating, Ismail is a person who has different ideological views with the government.

In looking at this phenomenon, we are directed to understand that all forms of articulation that are applied by state sovereignty give rise to submissive subjects. Hence, the key to understanding this is that the formation of two faces of the authority of sovereign power is the bending of the subject itself. In other words, all citizens are co-opted in the space between or zone of indistinction. Therefore, the conceptualization of political life moves towards the bare of life and makes it vulnerable to the law. The proportion of the law regarding the bare does not move towards saving freedom as a subject but is based on legal impotence, legal suspension of citizens' exceptions.

\subsection{The Anatomy of Sovereignty}

The foundation to understanding sovereignty is to examine the relationship between the state and its citizens. Both citizens and the government formalize the separate relationship between constituting and constituted power [23]. According to him, the formation of sovereignty is based on the separation of these two elements. The first element is constituting power or the power to form the constitution that moves from outside the realm of government. This energy or strength comes from the sovereignty of the people who are entitled to determine their own lives without political tendencies. Meanwhile, the definition of constituted power or the power of implementing the constitution refers to the government system, both executive and legislative in a country. The definition of this second element is inherent in the structure of modern democracy. 
However, the understanding of these two basic foundations of sovereignty is increasingly disintegrated, so that sovereignty becomes something abstract, absurd, and problematic. Agamben said that the two buildings should be the main capital in understanding who and what should be prioritized in the structure of state life. The discovery of how the two forms of the building have crystallized and incarnated as state figures is written in the quote below.

"Friendships were torn apart, and longstanding traditions were replaced by new hardships. And if we keep all these precedents in mind, should we not be willing to endure a bit of pain and inconvenience in the process of turning our state, the most powerful in the Middle East, into a model of a scientic, socialist, and industrial nation? While all these notions were buzzing inside my head, I had the sense that, by applying such logic, I could even manage to convince myself that death itself had its own particular requirements and benefits." (Mahfudz, 2008: 19).

The separation of these two foundations is very visible when what is a common will in the process of living together is met with big obstacles that come from the government element. The state, which is represented by the government, is narrated as an internal structure of state life that has a distance from its citizens. At the same time, this situation gives rise to separate parts in forming the structure of state life. On the one hand, citizens have to accept the consequences of the evolution of the state and the government keeps its distance from its discourse on sovereign stability on the other.

In the context of state life, certainly, various structures and elements included in the concept of nation and state are positioned as a rigid blueprint. This is the basic logic of how to overcome the separation of these two structures into a frame of common view. This logic is indeed very difficult to be done in the context of state life because in the structure of life there are complex problems. Given that, if conditions necessitate mobilization to raise problems, problems in the context of life are always filled with anxiety and filled with enigmatic feelings.

To interpret the above conditions, the main point that becomes the basis is a form of criticism of the construction of state sovereignty itself. State sovereignty is not an entity that has absolute power rights. It is always formed in a very rigid state structural fabric. Therefore, the first step towards another dimension of sovereignty is to restore the construction of state life in the context of the initial goal of forming the structure of state life.

Thus, the form of this criticism is on how the act of decentralizing the sovereign authority shapes a work pattern based on human values and spirit. The definition of decentralization of sovereignty does not mean eradicating all forms of political value, but rather leads to the restructuring of political life. Consequently, with this understanding, there is a utopia of political life that is unique to the centrifugal movement, namely to restore the dignity of state life from, for, and by the people with all forms of sovereignty.

The tendency used as a basis for arguments in the arrest was considered a concrete step towards the liminality of citizens. This form of liminality obscures Ismail's direction of where he should seek legal protection. In the landscape of a democratic country, the law has a sacred aspect, all of which are intended for citizens who are exposed to crime, because the power of the law has been expressed in the form of its suspension [23]. Therefore, the strong relationship that is reflected in the suspension of the law is an integral form of power itself.

Citizens' exceptions in the basic construction of sovereign power are transformed to appear more elegant. However, the focus of this construction creates bare life that is depicted between the forms of living animality and political life. The form of humanization in a democratic country is created in the form of the power of law as well as its exclusion. This binary opposition is continuously shown indisputably in social life thus stability can be conquered and maintained continuously. In considering this view radically, understanding the relationship between the political situation gives rise to norms and exceptions, between the forming and implementing powers of the constitution, all of which have ambiguity [24]. Accordingly, what happens is a state of exclusion of individuals or groups as the norm of ambiguity regarding the relevance of the structure of social life.

In the implementation, the exclusion is the main way to restore the nature of sovereignty. This exception, as stated by Agamben, as an act of desubjectivation, is individual or group in nature, occurs temporally, and can be said to occur continuously. However, the process of creating prisons as part of a modern democratic state makes it possible as a location for discipline.

"The only thing I came into contact with was the walls; there was absolutely nothing in the room, no chairs, no rug, nothing standing at 
all. Darkness, emptiness, despair, terror, that was it. In a dark and silent environment like that, time stops altogether; since I had no idea when they had picked me up, that was even more the case. I had no idea when the darkness was supposed to disappear or when some form of life would emerge from this all embracing corpse of a place" (Mahfudz, 2008: 43).

The inclusion of Ismail in a prison cell is a concentration on the charges against him. This is made worse by the treatment Ismail experienced when he was processed without going through the stages of the court. Now all he feels is pain followed by the condition of the cells which can be said to be less than proper. Under such conditions, Ismail lost the balance between the law as his security or even in the sense of suspending his function. This is a paradox of sovereignty with its strong relation to the law that can be categorized into its form of impotence, as well as historical evidence without any relevance to the basic principles of democracy.

The implementation of the exception measures by putting Ismail in prison essentially proves that the regulation of state life is the matrix of modern democracy, showing anomie of normative life from the establishment of sovereign power. The flexibility of this exception emphasizes that the picture of political life is transformed in the form of biopolitics through the formal legal rationalization of government [25]. At this point, Ismail's condition while in prison is a form of paradox that makes it an illustration of the paradoxicality of the state security structure. Therefore, Ismail's body becomes an illustration of the consequences when exceptions become an integral part of the state.

The practice of a democratic state as in the contemporary era is understood as the principle of forming sovereignty based on the power of the people. This understanding is disseminated as well as the meaning of democracy from conventional meanings in general. This basic understanding of democracy is based on the power of authority that seeks to mobilize and regulate the form of government to be realized together. What attracts Agamben in understanding the reality of democracy is from the point of view of the creation of all citizens in political life. It is at this point that Agamben's main criticism is that the meaning of democracy today is a form of political exception for citizens who are engaged in the scope of biological life [26].

On the one hand, the above understanding can be positive if it moves in a progressive direction that offers the attributes of freedom of public space for all citizens. However, this situation can also neglect the space of freedom so that what happens is the formation of a catastrophe in a democratic space [27]. In other words, how the consequences of cultural improvisation spread throughout the structure of life. Cultural improvisation will be a bridge to see how this cultural-based sense of humanity can become the main goal in gaining sovereignty.

Thus, the issue of the existence of citizens in prison is no longer a question of conflicting views in terms of the state. When he was put in a camp, it became a process of full concentration on the reduction of basic law. Therefore, the politics of citizenship inevitably merges with the politics of state sovereignty. The result of such a process wants a subject who is obedient even though the substance is contrary to profane life.

\section{CONCLUSION}

Based on the explanation above, there is an ambivalence or ambiguity related to the social reality described by Najib Mahfudz in the novel al-Karnak. This ambiguity is present in the construction of a democratic state that closes itself in the form of shaping a harmonious state of life. However, when the country is in the midst of conflict, the government has the right to issue a decree in the form of suspending the constitution to reduce, improve, and show its toughness in front of citizens.

However, what happened was not universal social justice. In its execution, dehumanization practices are often found by erasing and releasing the construction of citizens' human rights as human beings. As in several quotes about the narrative of the characters in the novel, these characters are described as citizens who are used as objects of power. In other words, these figures have experienced legal reduction and entered life in the frame of political calculations. Thus, this treatment has legitimacy that is confirmed by the assumption of state security.

\section{REFERENCES}

[1] D. F. DiMeo, "Egypt's Police State In The Work Of Idris And Mahfouz", CLCWeb: Comparative Literature and Culture 14(4) (2012) 3.

[2] S. Mehrez, The Literary Life Of Cairo: One Hundred Years In The Heart Of The City, Oxford: University Press, 2011

[3] Abu-Rabi', I. M. (2004). Contemporary Arab Thought: Studies In Post-1967 Arab Intellectual History. Pluto Press. 
[4] Kamil, S. (2008). Sejarah Prosa Imaginatif (Novel) Arab; Dari Klasik Hingga Kontemporer. LiNGUA: Jurnal Ilmu Bahasa Dan Sastra, 3(2).

[5] Munthe, B. (2008). Wanita Menurut Najib Mahfuz (Telaah Strukturalisme Genetik). Yogyakarta: UIN Yogyakarta.

[6] Allen, R. (1977). Some Recent Works of Najîb Mahfûz: A Critical Analysis. Journal of the American Research Center in Egypt, 14, 101110.

[7] Manshur, F. M. (2012). Teori Sastra Marxis Dan Aplikasinya Pada Penelitian Karya Sastra Arab Modern. Bahasa Dan Seni: Jurnal Bahasa, Sastra, Seni, Dan Pengajarannya, 40(1).

[8] Bourdieu, P. (1990). The Logic of Practice. Stanford university press.

[9] Agamben, G. (1999). The man without content. Stanford University Press.

[10] Suweleh, F. (2020). Karakteristik Heterotopia Ruang Kafe Dalam Al-Karnak Karya Najib Mahfudz: Analisis Other Space Michel Foucault. Universitas Gadjah Mada.

[11] Purnomo, M. D. (2016). Pandangan Dunia Dalam Novel Al-Karnak Karya Najib Mahfudz Analisis Strukturalisme Genetik Goldmann. Universitas Gadjah Mada.

[12] Zahra, S. L. (n.d.). Pencerita dan Teknik Penceritaan dalam Novel Al-Karnak Karya Naguib Mahfudz. On Line Available: http://lib. ui. ac. id/file.

[13] Fahruddin, M. A. (2018). Analisis Struktural Pada Novel Al-Karnak Karya Najib Mahfudz. Skripsi Jurusan Sastra Arab-Fakultas Sastra UM

[14] Benjamin, W. (2007). Critique of violence. In On Violence (pp. 268-285). Duke University Press.

[15] Primera Villamizar, G. E. (2014). Potentiality, Sovereignty And Bare Life A Critical Reading of Giorgio Agamben. Ideas y Valores, 63(156), 7999.
[16] Humphreys, S. (2006). Legalizing Lawlessness: On Giorgio Agamben's State Of Exception. European Journal of International Law, 17(3), $677-687$.

[17] Foucault, M. (2003). Madness and Civilization. Routledge.

[18] Foucault, M. (1978). The Eye of Power.

[19] Faruk, H. T. (2012). Metode Penelitian Sastra: Sebuah Penjelajahan Awal. Pustaka Pelajar.

[20] Schmitt, C. (2005). Political Theology: Four Chapters On The Concept Of Sovereignty. University of Chicago Press.

[21] Farrier, D., \& Tuitt, P. (2013). Beyond Biopolitics: Agamben, Asylum And Postcolonial Critique.

[22] Fitzpatrick, P. (2005). Bare Sovereignty: Homo Sacer And The Insistence Of Law. In Politics, Metaphysics, and Death (pp. 49-73). Duke University Press.

[23] Agamben, G. (1998). Homo sacer: Sovereign power and bare life. Stanford University Press.

[24] Huysmans, J. (2008). The Jargon of ExceptionOn Schmitt, Agamben and The Absence of Political Society. International Political Sociology, 2(2), 165-183.

[25] Neal, A. W. (2006). Foucault In Guantánamo: Towards An Archaeology Of The Exception. Security Dialogue, 37(1), 31-46.

[26] Mills, C. (2014). The Philosophy of Agamben. Routledge.

[27] Snoek, A., \& Fry, C. L. (2015). Lessons In Biopolitics And Agency: Agamben On Addiction. The New Bioethics, 21(2), 128-141. 